\title{
HISTOPLASMOSIS IN RIO GRANDE DO SUL, BRAZIL: A 21-YEAR EXPERIENCE
}

\author{
Luiz Carlos SEVERO(1), Flávio de Mattos OLIVEIRA(2), Klaus IRION(3), Nelson da Silva PORTO(3) \& Alberto Thomaz LONDERO(4)
}

\begin{abstract}
SUMMARY
Of 156 cases of histoplasmosis observed in the State of Rio Grande do Sul (Brazil), during a 21-year period (1978-1999) 137 were included in this study. Sixty-seven per cent of the patients had hematogeneous disseminated histoplasmosis, $24 \%$ had a selflimited syndrome (acute pulmonary histoplasmosis, histoplasmoma or primary pulmonary lymph node complex), and 9 per cent had chronic pulmonary histoplasmosis. Clinical, mycological, and epidemiological data were reviewed and commented.
\end{abstract}

KEYWORDS: Histoplasmosis; Histoplasma capsulatum; HIV infection; Brazil.

\section{INTRODUCTION}

Before 1980 only three small surveys of histoplasmin skin test were performed $^{6,10,11}$ and four cases of histoplasmosis were reported ${ }^{1,5}$ or quoted $^{2}$ in natives of the State of Rio Grande do Sul. However, since 1981 thirty nine cases of the mycosis have been published ${ }^{3,7-9,12,14,16,18-24}$. In addition, in 1996 a histoplasmin skin test survey revealed 89 per cent of reactors amongst young men aged between 17 to 19 years of age, living in the Jacuí River valley ${ }^{26}$.

The increase in the number of recognized cases of histoplasmosis and the existence of an high endemic area in the state led us to review the clinical protocols of 137 native patients diagnosed in Porto Alegre, in the period between 1978 and 1999. A comment on our findings is presented.

\section{PATIENTS AND METHODS}

The clinical and microbiological protocols of 156 patients with histoplasmosis, diagnosed in a 21-year period (1978-1999), in Porto Alegre, were reviewed. Criteria for diagnosis included: detection of the microorganism resembling $H$. capuslatum var. capsulatum in tissue cut sections stained by Gomori's methenamine silver (GMS) or by isolation in culture or both. Less frequently by serology (complement fixation test or immunodiffusion test) associated with the existence of compatible symptoms.

\section{RESULTS}

One hundred and thirty seven of the 156 patients were native of Rio Grande do Sul. One hundred and one were males and 36 were females; with age ranging from 19 months to 77 years (average 37 years); 129 were Caucasian and 8 were black.

The distribution of these patients by the clinical forms they presented was as follow: primary pulmonary lymph node complex (4 cases); acute pulmonary histoplasmosis (19 cases); residual lesions (10 cases); chronic pulmonary histoplasmosis (12 cases); and, disseminated histoplasmosis (92 patients).

Primary pulmonary lymph node complex: Primary pulmonary lymph node complex was recognized by chance in four patients (aged between 21-42 years), one man and three females. All patients had been submitted to surgery due to a carcinoid tumor, an adenocarcinoma, a hydatic cyst and an Aspergillus fumigatus fungus ball, respectively. Calcified lung lymph node lesions were detected and histologically examined. Yeast forms of $H$. capsulatum var. capsulatum were disclosed in GMS stained cut of the lung and of the lymphnodes.

Acute pulmonary histoplasmosis: Nineteen patients presented this form of the disease. Eighteen of them fulfilled the diagnostic criteria of a primary type of acute pulmonary histoplasmosis: an acute onset of symptoms (cough, weight loss, fever, and night sweats) associated with a radiologic picture of diffuse micronodular lesions in both lung fields. In three of the patients bilateral lymph node enlargement was also observed. Twelve of these patients were males and 6 females, with ages ranging from 8 to 59 years. With the exception of seven cases diagnosed as a group ( 3 patients of a same family, two brothers and a couple), the remaining infections occurred in an isolated fashion. Six of these cases were previously published ${ }^{18-20,22}$.

One of the remaining patients presented the reinfection type of acute

\footnotetext{
(1) Pesquisador do CNPq; Faculdade de Medicina, Universidade Federal do Rio Grande do Sul (UFRGS), RS, Brasil.

(2) Laboratório de Microbiologia Clínica, Instituto Especializado em Pesquisa e Diagnóstico (IPD), Santa Casa, RS, Brasil.

(3) Pavilhão Pereira Filho, Santa Casa, RS, Brasil.

(4) Universidade Federal de Santa Maria, Santa Maria, RS, Brasil.

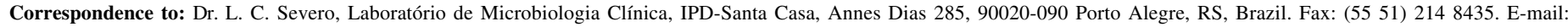
severo@santacasa.tche.br
} 


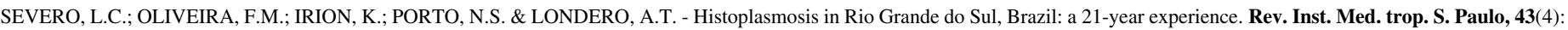
$183-187,2001$.

pulmonary histoplasmosis. She was a 39 year-old woman who became ill following a heavy exposure while cleaning the same chicken house where she was primarily infected one year before. Another patient presented with a mild disease with flu-like symptoms and non calcified lung lesions (Fig. 1).

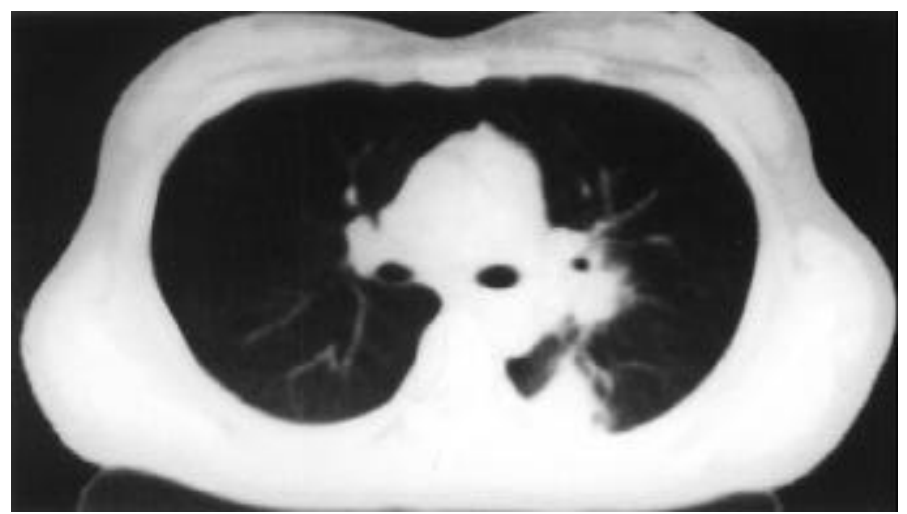

Fig. 1- Primary pulmonary histoplasmosis, diagnosed by transthoracic fine needle aspiration: CT scan shows in the right lung a focus of consolidated parenchyma, hilar lymph node enlarged, and a linear opacity between them.

Diagnosis was based on histologic examination of biopsied lung tissue in 12 patients; on immunodiffusion test in five patients; and on the similarity of the disease that appeared concomitantly in the 3 members of a family, one of which was biopsied.

The natural source of the infection was established by the isolation of $H$. capusulatum var. capsulatum from chicken manure (6 cases); it was presumed to be from chicken manure ( 6 cases) or from bat guano ( 5 cases); and, in two cases the source of the infection remained unknown.

Ten patients improved spontaneously, 9 were treated with ketoconazole or itraconazole. Five of the 19 patients had been treated for tuberculosis prior to the diagnosis.

Histoplasmoma: Ten asymptomatic patients presented well circumscribed, non calcified pulmonary nodule, ranged from $9 \mathrm{~mm}$ to 2 $\mathrm{cm}$ in diameter (Fig. 2). Eight patients had a solitary nodule; one patient 2 nodules; and, the remaining 3 nodules. Eight cases were detected by chance on screening chest X-ray; 2 cases were detected in ressected lung for carcinoma. The ten patients ranged from 10 to 67 years of age; five were males and 5 females.

Chronic pulmonary histoplasmosis: Chronic pulmonary histoplasmosis was diagnosed in 12 patients with ages between 14 to 64 years. All presented symptoms either of a chronic pulmonary infection or of a chronic obstructive disease. Radiologically, non-cavitate pulmonary infiltrates were observed in 8 patients; and, large cavities in both upper lobes in 4 patients. Diagnosis was obtained by histologic examination of biopsied lung tissue in 10 patients and isolation of the fungus from bronchoalveolar lavage specimen in 2 patients.

In 3 of the 4 patients with cavitary disease an A. fumigatus fungus ball developed after they were clinically cured of the histoplasma infection (Figs. 3 and 4). One of these patients was a subject of report prior to being colonized ${ }^{21}$.

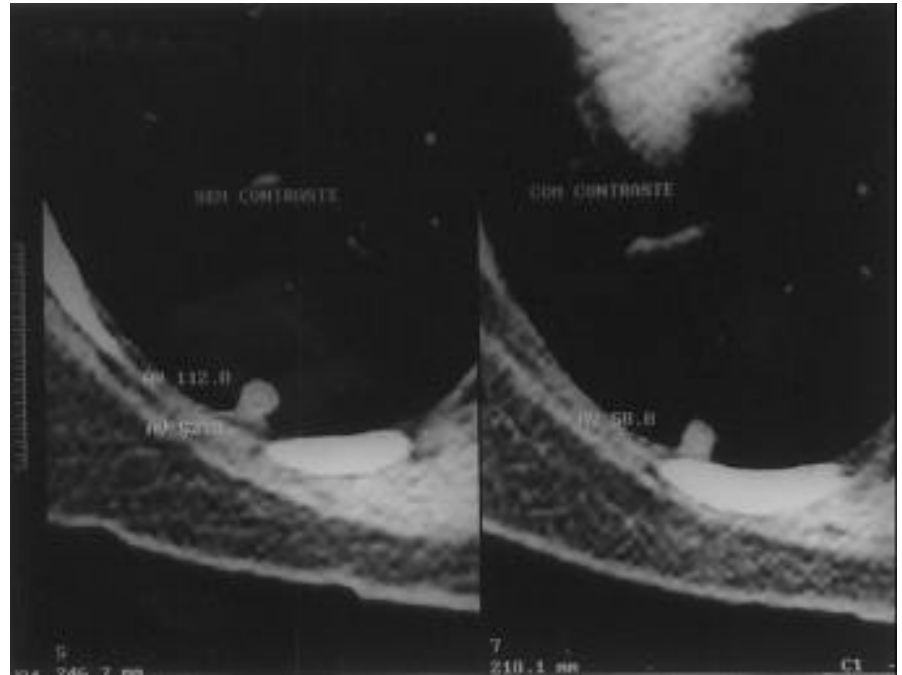

Fig. 2 - Histoplasmoma: CT scan shows well-circumscribed subpleural nodule.

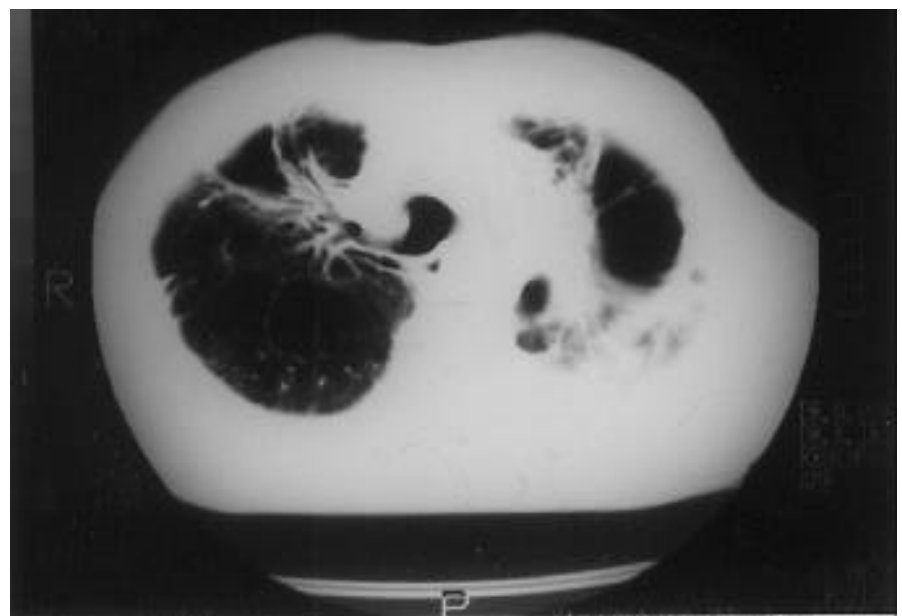

Fig. 3 - Treated chronic pulmonary histoplasmosis: CT scan shows empty cavities in both upper lobes.

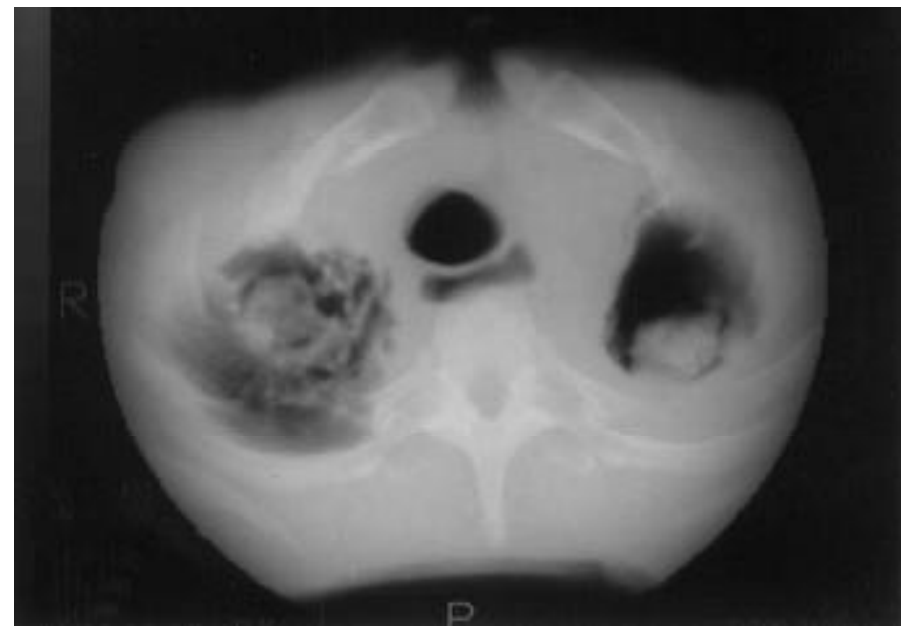

Fig. 4 - The same patient from figure 3: developed bilateral A. fumigatus fungus ball. 
Disseminated histoplasmosis: Ninety-two (67\%) of the 137 patients presented the disseminated form of the mycosis. With the exception of one child, case previously reported ${ }^{24}$, with the acute form, the remaining patients in which ages varied between 22 to 77 years had the chronic disseminated type. Seventeen of these patients had no evidence of any associated condition, 65 had HIV infection, 4 had diabetes mellitus, 3 had lymphoma, one was under therapy with cytotoxic agents, and one was a kidney allograft recipient.

The diagnosis was established by disclosing the fungus in GMS stained cut sections of biopsied tissue (75 of 81 patients), or by isolation of the fungus in culture (42 of 56 patients), or by both techniques. Blood culture (Isolator) and culture of broncoalveolar lavage specimen were more helpful for the diagnosis in HIV infected patients. The immunodiffusion test was performed in 53 patients with positive results in $62 \%$ of them.

Multiple organs, as usual, were involved, but their number and frequency varied according the predisposing conditions (Table 1). The lung was the most frequently affected organ in both groups: AIDS (Fig. 5) and non-AIDS patients (Figs. 6 and 7). Curiously the involvement of the CNS and of the adrenal glands was observed more frequently in patients in which no predisposing conditions were detected. Involvement of the CNS was documented in 4 AIDS patients and in 9 patients presenting no evidence of associated conditions. In 5 of these 9 patients, all of them presenting signs of chronic meningitis and hydrocephalus (Fig. 8), the fungus was detected at the time of the ventricular-peritoneal shunt replacement due to an unexplained and repeated occlusion (3 to 5 times) of the prosthetic device. In one of the AIDS patients tuberculosis and cryptococcosis were associated. Involvement of the adrenal was only observed in non-AIDS patients: in one of them calcified areas were observed in both glands (Figs. 9 and 10).

\section{Table 1}

Organ involvement in 91 patients presenting with chronic disseminated form of histoplasmosis

\begin{tabular}{lccc}
\hline Involved organ & \multicolumn{3}{c}{ Predisposing conditions } \\
\cline { 2 - 4 } & AIDS & Not known & Others* \\
& $65(\%)$ & $17(\%)$ & $9(\%)$ \\
\hline Lungs & $37(56.9)$ & $13(76.5)$ & $2(22.2)$ \\
Skin & $31(47.6)$ & $02(11.7)$ & $2(22.2)$ \\
Lymphnodes & $15(23.0)$ & $01(05.9)$ & $2(22.2)$ \\
Oropharynx & $13(20.0)$ & $04(22.2)$ & $2(22.2)$ \\
Liver & $12(18.4)$ & $01(05.9)$ & 0 \\
Bone marrow & $09(13.8)$ & 0 & 0 \\
Central nervous system & $04(06.1)$ & $09(47.0)$ & 0 \\
Spleen & $04(06.1)$ & $01(05.9)$ & 0 \\
Genito urinary tract & $03(04.6)$ & 0 & $1(11.1)$ \\
Thyroid & $01(01.5)$ & 0 & 0 \\
Heart and joints & $01(01.5)$ & 0 & 0 \\
Pancreas & $01(01.5)$ & 0 & 0 \\
Adrenal & 0 & $03(17.6)$ & $2(22.2)$ \\
Larynx & 0 & $01(05.9)$ & $2(22.2)$ \\
\hline
\end{tabular}

* Diabetes mellitus (4 patients); lymphoma (3 patients); and therapy with cytotoxic agents for multiple mieloma and renal allograft recipient (one patient each)

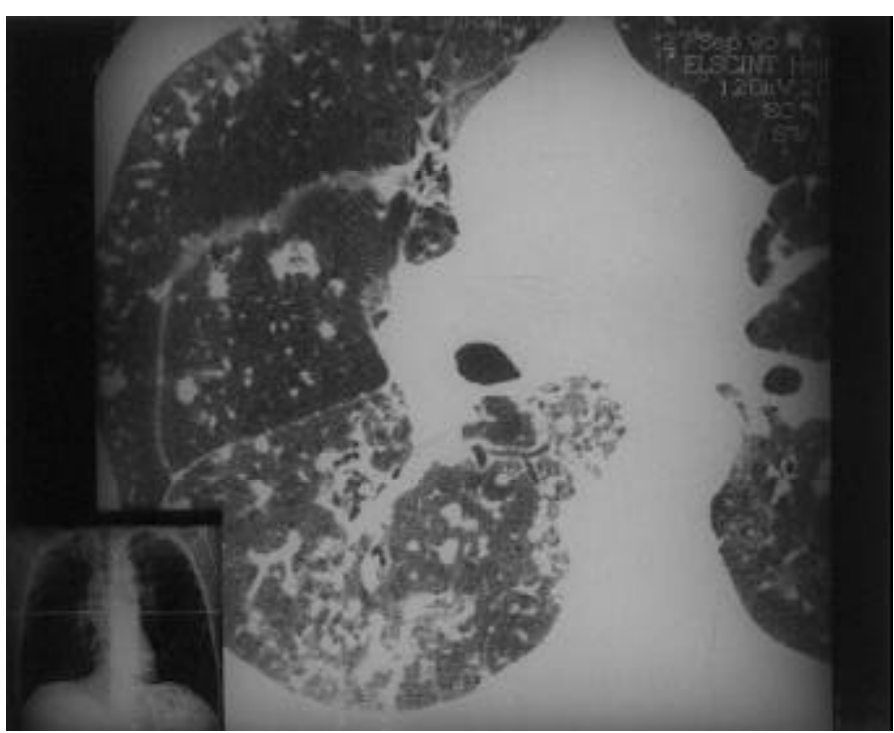

Fig. 5 - Disseminated histoplasmosis in AIDS-patient, diagnosed by thransbronchial biopsy.

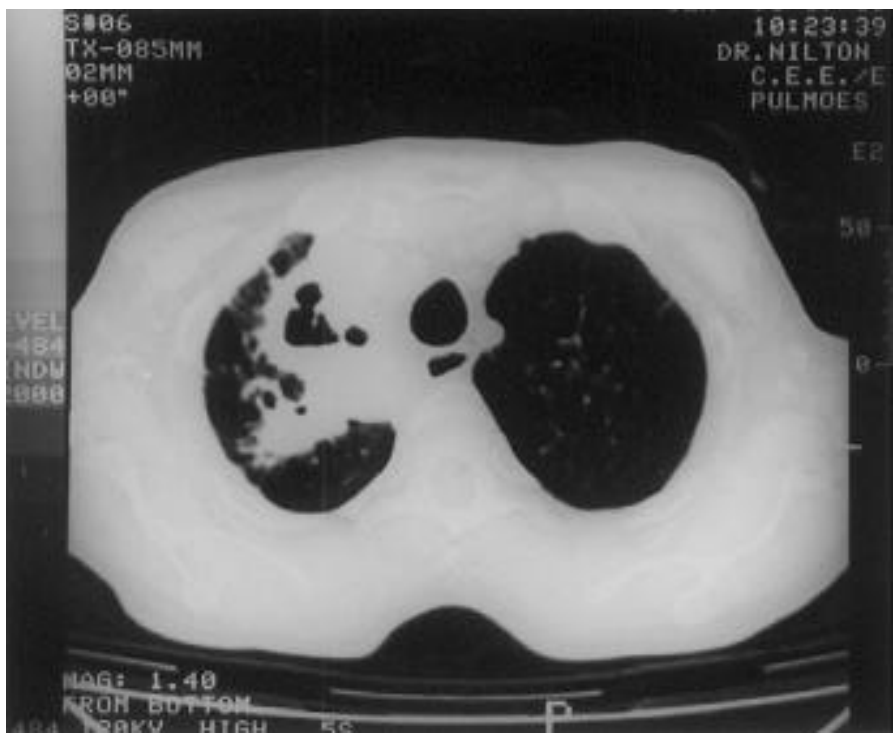

Fig. 6 - Disseminated histoplasmosis in a diabetic patient: CT scan shows a consolidation and cavity with air-fluid interface in the left upper lobe.

\section{DISCUSSION}

Histoplamosis is endemic in the State of Rio Grande do Sul particularly in the Jacuí river valley, where $H$. capsulatum var. capsulatum was isolated from soil ${ }^{18}$ and 89 per cent of the young men were reactors to histoplasmin skin test ${ }^{26}$.

Almost all the clinical forms of the disease have been recognized to occur in natives of the State.

Three findings are interesting to note. The first one: delays in diagnosis of disseminated histoplasmosis complicating AIDS are most frequently a result of not performing a biopsy in a mucocutaneous lesion. The second one: in three of the four patients with cavitate chronic 


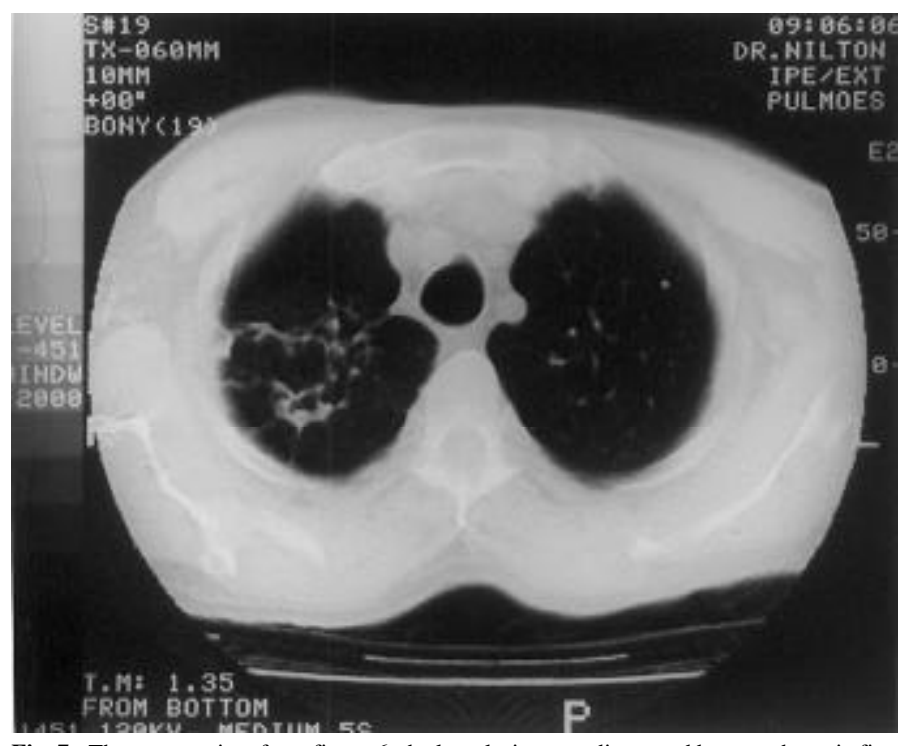

Fig. 7 - The same patient from figure 6: the lung lesion was diagnosed by transthoracic fine needle aspiration and successfully treated with itraconazole: CT scan one-year later showing the resolution of the lung lesions.

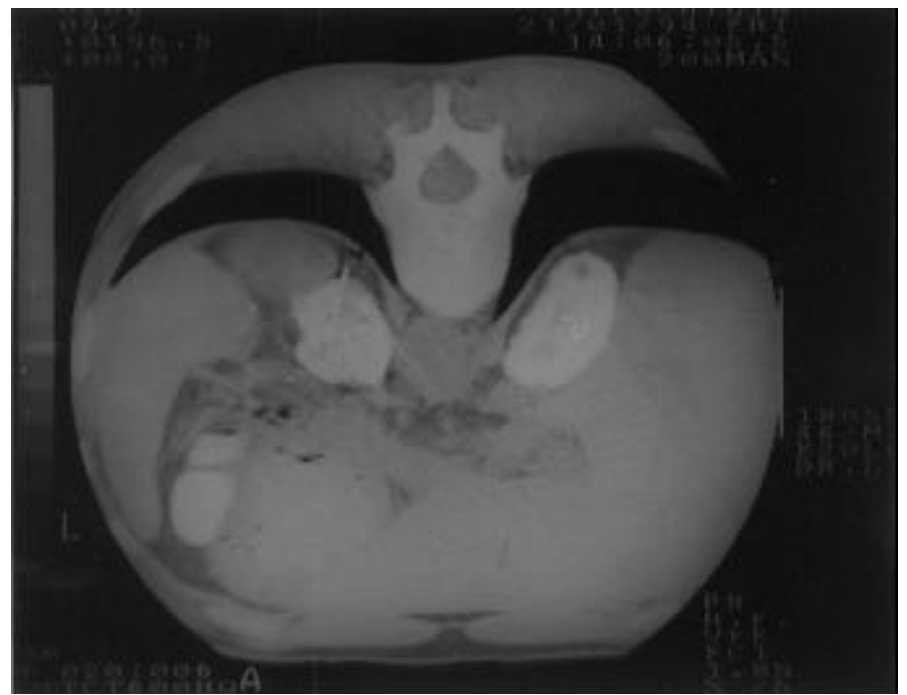

Fig. 9 - Disseminated histoplasmosis: CT scan shows calcified areas in both adrenals.

pulmonary form, the cavity was colonized by A. fumigatus after they were clinically cured. The third one: five patients with chronic meningitis and hydrocephalus needed a shunt replacement due to the obstruction of the prothetic device by $H$. capsulatum var. capsulatum. Aspergillus fungus ball developed in a cavitation of chronic pulmonary histoplasmosis was reported as early as $1960^{15}$. Malfunction ventricular shunt caused by $H$. capsulatum var. capsulatum has been documented only rarely $y^{4,13,17,25}$, in one of the patients ${ }^{4}$ the mycosis was only recognized after the isolation of the fungus in culture of the ventricular fluid. Immunologic testing of cerebrospinal fluid should be considered in this kind of patients ${ }^{13}$.

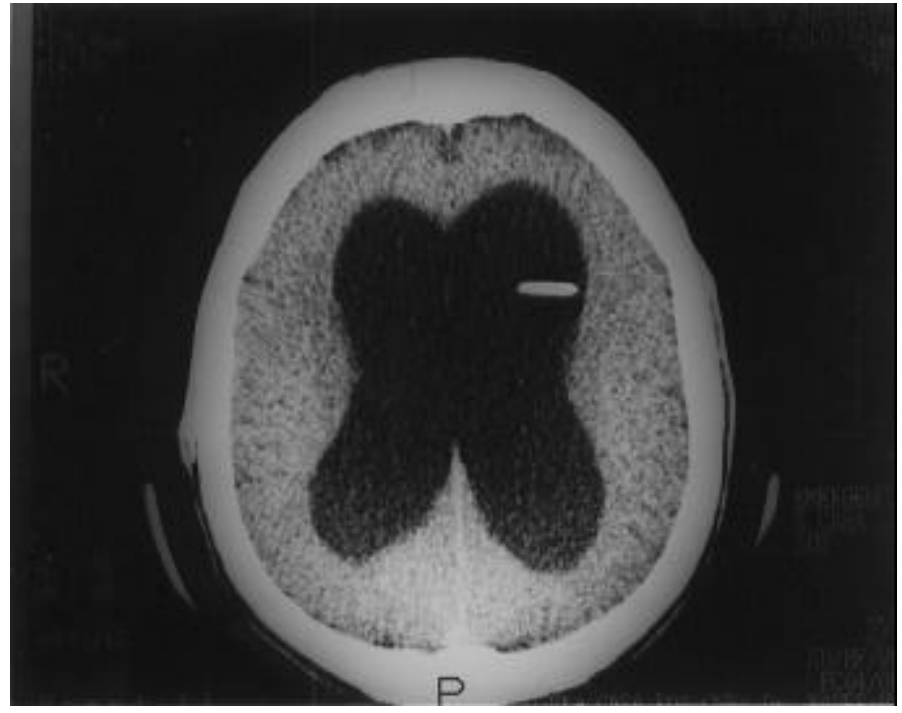

Fig. 8 - Disseminated histoplasmosis presented as chronic meningitis and hydrocephalus: CT scan showing ventricle enlargement and the ventricular-peritoneal shunt.

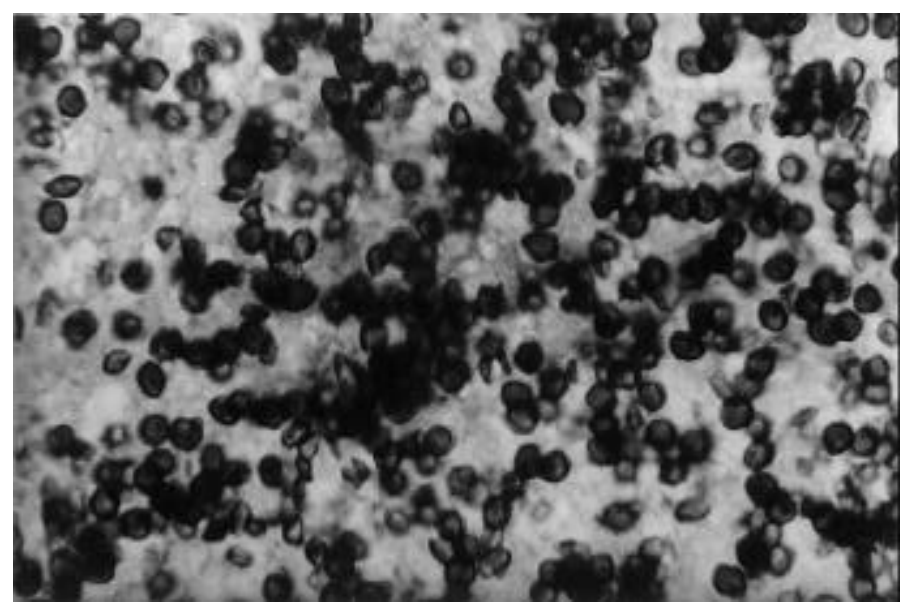

Fig. 10 - Disseminated histoplasmosis involving the adrenal gland: the fungal cells are numerous and well demonstrated by GMS (x500).

\section{RESUMO}

\section{Histoplasmose no Rio Grande do Sul, Brasil: uma experiência de 21 anos}

De 156 casos de histoplasmose observados no Estado do Rio Grande do Sul (Brasil), durante um período de 21 anos (1978-1999), 137 foram incluidos neste estudo.

Sessenta e seis porcento dos pacientes tinham histoplasmose de disseminação hemática, 24\% tinham uma síndrome autolimitada 
(histoplasmose pulmonar aguda, histoplasmoma ou complexo primário linfonodo-pulmonar) e $9 \%$ tinham histoplasmose pulmonar crônica. Os dados clínicos, micológicos e epidemiológicos foram revisados e comentados.

\section{ACKNOWLEDGEMENTS}

We are gratefully acknowledged to Dr Leo Kaufman (CDC, Atlanta, GA, USA) for performing serologic assays in the beginning of this study, afterwards providing antigens for immunodiffusion tests and identification of one strain of $H$. capsulatum var. capsulatum by exoantigen (in isolate without macroconidia, CDC 92-033214).

\section{REFERENCES}

1. AGOSTINI, A.; OMIZZOLO, F.; LONDERO, A.T. \& DEGRAZIA, C.O. - Histoplasmose no Brasil. Apresentação de um caso. Hospital (Rio de J.), 68: 173-178, 1965.

2. CARNEIRO, J.F. - Micoses pulmonares no Brasil. Rev. Serv. nac. Tuberc., 4: 183-210, 1960.

3. COUTINHO, L.M.B.; GELPI, A.L.; ANICET, A. et al. - Histoplasmomas encefálicos múltiplos. Estudo autopsico de um caso. Arq. Neuro-psiquiat. (S. Paulo), 39: 341349,1981 .

4. ENARSON, D.A.; KEYS, T.F. \& ONOFRIO, B.M. - Central nervous system histoplasmosis with obstructive hydrocephalus. Amer. J. Med., 64: 895-896, 1978.

5. FAGUNDES, L.A. \& LIMA, J.P. - Histoplasmose. Apresentação de 1 caso. Med. Cirurg. Farm., 280: 170-174, 1960.

6. FISCHMAN, O. - Inquérito histoplasmínico. Dados obtidos sobre 113 universitários, em Santa Maria. Rev. Fac. Agro. Vet. UFRGS, 2: 45-51, 1959.

7. LOPES, J.O.; ALVES, S.H.; BENEVENGA, J.P.; REGIO, O.R. \& CALIL, A. Histoplasma capsulatum peritonitis associated with continuous ambulatory peritoneal dialysis. Mycopathologia (Den Haag), 122: 101-102, 1993.

8. LOPES, J.O.; ALVES, S.H.; BENEVENGA, J.P. \& ROSA, A.C. - The second case of peritonitis due to Histoplasma capsulatum during continuous ambulatory peritoneal dialysis in Brazil. Mycoses, 37: 161-163, 1994.

9. LOPES, J.O.; STREHER, L.A.; SCHOPF, L.F. et al. - Lesões cutâneas na histoplasmose disseminada progressiva associada com SIDA. Rev. Soc. bras. Med. trop., 27: 171$174,1994$.

10. MARSIAJ, N.; PY, A. \& PÊGAS, N. - Primeiras pesquisas sobre sensibilidade cutânea à histoplasmina no Estado do Rio Grande do Sul. Rev. bras. Med., 7: 157-163, 1950.

11. MARSIAJ, N.; GUIMARÃES, N.; CUNHA, P. \& LIMA, A.D. - Investigações prelimanares sobre a incidência da sensibilidade cutânea à histoplasmina no Brasil. Hospital (Rio de J.), 36: 167-171, 1949.

12. MEZZARI, A. ; CAUDURO, P.F.; DIAS, C.A. \& CARDONI, M.G. - Histoplasma capsulatum: relato de um caso em aidético. Rev. ass. méd. Rio Gr. Sul, 36: 294296, 1992.
13. NEGRONI, R.; ROBLES, A.M.; ARECHAVALA, A. et al. - Chronic meningoencephalitis due to Histoplasma capsulatum. Usefulness of serodiagnostic procedures in diagnosis. Serodiagn. Immunother. infect. Dis., 7: 84-89, 1995.

14. PINOTTI, A.F.F.; SEVERO, L.C.; RANDON, M.; RIGATTO, M. \& HAASE, H.B. Histoplasmose disseminada associada à tuberculose em pacientes imunodeprimidos. Rev. Ass. méd. bras., 29: 68-70, 1983.

15. PROCHNOW, J.J. \& LOEWEN, D.F. - Pulmonary aspergillosis in cavitation secondary to histoplasmosis. Amer. Rev. resp. Dis., 82: 101-111, 1960.

16. ROCHA, M.M. \& SEVERO, L.C. - Histoplasmose disseminada em pacientes com síndrome de imunodeficiência adquirida (SIDA). Estudo de 25 casos. Rev. Inst. Med. trop. S. Paulo, 36: 167-170, 1994.

17. SCHWARTZ, J.G.; TIO, F.O. \& FETCHICK, R.J. - Filamentous Histoplasma capsulatum involving a ventriculoartrial shunt. Neurosurgery, 18: 487-490, 1986.

18. SEVERO, L.C.; PETRILLO, V.F.; CAMARGO, J.J.; GEYER, G.R. \& PORTO, N.S. Acute pulmonary histoplasmosis and first isolation of Histoplasma capuslatum from soil of Rio Grande do Sul, Brazil. Rev. Inst. Med. trop. S. Paulo, 28: 51-55, 1986.

19. SEVERO, L.C.; PICON, P.D.; LONDERO, A.T. \& RUBIÃO FILHO, H.J. - Histoplasmose aguda. Relato de dois casos. Rev. ass. méd. Rio Gr. Sul, 25: 64-67, 1981.

20. SEVERO, L.C.; KAEMMERER, A. \& CHAIEB, J.A. - Histoplasmose aguda em criança Relato de um caso e revisão da literatura brasileira. J. Pediat. (Rio de J.), 25: 237 $238,1982$.

21. SEVERO, L.C.; RIZZON, C.F.C.; ROESCH, E.W.; OLIVEIRA, F.M. \& PORTO, N.S. Chronic pulmonary histoplasmosis in Brazil: report of two cases with cavitation diagnosed by transthoracic needle biopsy. Rev. Inst. Med. trop. S. Paulo, 39: 293$297,1997$.

22. SEVERO, L.C.; RIZZON, C.F.C.; ROESCH, E.W. \& PORTO, N.S. - Histoplasmose pulmonar aguda: episódio em casal de adultos. Rev. ass. méd. Rio Gr. Sul, 37: 281$283,1993$.

23. SEVERO, L.C. \& ROCHA, M.M. - Histoplasmose disseminada associada à SIDA Apresentação de caso e revisão de aspectos diagnósticos. Rev. ass. méd. Rio Gr. Sul, 32: 113-115, 1988

24. SEVERO, L.C.; ZARDO, I.B.; ROESCH, E.W. \& HARTMANN, A.A. - Acute disseminated histoplasmosis in infancy in Brasil: report of a case and review. Rev. iberoamer. Micol., 15: 48-50, 1998.

25. TIRABOSCHI, I.; CASAS PARERA, I.; PIKIELNY, R.; SCATTINI, G. \& MICHELI, F. - Chronic Histoplasma capsulatum infection of the central nervous system successfully treated with fluconazole. Europ. Neurol., 32: 70-73, 1992.

26. ZEMBRZUSKI, M.M.; BASSANESI, M.C.; WAGNER, L.C. \& SEVERO, L.C. Inquérito intradérmico com histoplasmina e paracoccidioidina em duas regiões do Rio Grande do Sul. Rev. Soc. bras. Med. trop., 29: 1-3, 1996.

Received: 27 February 2000

Accepted: 19 March 2001 